
TEXHIKA

\author{
DOI: 10.20535/kpi-sn.2019.4.177082 \\ UDC 535.2:616-71
}

\author{
M.O. Bezuglyi*, N.V. Bezugla, D.V. Horban \\ Igor Sikorsky Kyiv Polytechnic Institute, Kyiv, Ukraine \\ *corresponding author: m.bezuglyi@kpi.ua
}

\title{
DETERMINATION OF THE TISSUE ANISOTROPY FACTOR DURING THE PHOTOMETRY BY ELLIPSOIDAL REFLECTORS
}

\begin{abstract}
Background. The features of scattering anisotropy factor determination in the research of thick biological tissue samples. Objective. The purpose of the paper is development and testing of new method of tissue scattering anisotropy factor determination. The method is based on the analysis of illuminance of different zones of photometric images, received during the photometry by ellipsoidal reflectors.

Methods. For implementation of ideas and assumptions, the paper applies basics of photometry by ellipsoidal reflectors for real and model experiments, with the implementation of direct and inverse Monte Carlo method for light propagation in biological tissue. Additionally, principles of zone analysis of photometric images illuminance, received during the photometry by ellipsoidal reflectors, are applied.

Results. Based on the results of real experiment, the research represents input data set for Monte Carlo simulation of light propagation in biomedical photometer with ellipsoidal reflectors. Considering the modeling, the selection of critical thickness of samples of chicken and porcine muscle tissues was reasoned for further comparison with the results of real experiment. Dependencies of illuminance of different zones of photometric images for the selected thicknesses in the significant range of anisotropy factor value change were received. Anisotropy factors were determined in the spatial scattering cross sections. There was performed the comparative evaluation of character of photometric image zone illumination dependency for samples of various muscle tissues of similar thickness, and different thicknesses of selected tissue. Based on the developed method the specificities of real experiment results reproduction during the determination of scattering anisotropy factor by the illuminance values of photometric images, received during the simulation are shown.

Conclusions. Method of the mirror ellipsoid of revolution (which was used during the experiment with biological tissues samples in reflected and transmitted light) isn't limited by the functionality of preliminary estimation of quantity of cross section for further spatial analysis and investigation of scattering indicatrix. Photometry by ellipsoidal reflectors can be applied as the separate method for determination of the magnitude of the scattering anisotropy factor based on the results of model and numerical experiments, and the developed procedure.
\end{abstract}

Keywords: ellipsoidal reflector; photometry; scattering anisotropy factor; tissue anisotropy factor.

\section{Introduction}

Scattering anisotropy factor is one of the indicators, determining optical properties of biological tissue. Scattering and absorption coefficients, and refractive index form the biometrical basis, with the help of which the identification of biological media is possible. The goal of such identification is determination of changes, caused by various pathologic processes [1-6].

From the analytic interpretation standpoint, the tissue anisotropy factor is the probability characteristic, which reveals the phase scattering function in the main equation of radiative transfer theory $[7,8]$. For biophotonics methods and means for various biological tissues, the one-time Mie scattering and Reynolds-McCormick (RMPF), Eddington and Delta-Eddington, and Henyey-Greenstein (HGPF) phase functions are most widely used. Besides, the HGPF is considered as the best standard for simulation of light propagation in biological tissues (BT), and, therefore, for solution of inverse tasks in optical biomedical diagnostics [9-12]. During the transition to the one-time scattering function based on the measured scattering indicatrix on the thick biological samples, mathematical apparatus for goniometric measurements is used [13-17].

Among used technical tools for determining the optical properties of tissues based on the measured optical coefficients of transmittance and reflectance, photometers with ellipsoidal reflectors (ER) can be considered as the most informative ones [18]. They can be considered as the successful alternative for integrating spheres. Photometers with ellipsoidal reflectors, used in combination with ray-tracing principles in biological tissue and ellipsoidal reflector [19], and Monte Carlo simulation of light propagation, allow estimating the spatial distribution of forward and back scattered light on various laser source parameters [20]. 
The proceedings [21-23] represent that the scattering anisotropy has non-axial symmetry character, which is extremely true for fiber biological tissues. In such case, photometry by ellipsoidal reflectors is used as the method of preliminary estimation of the asymmetry of scattering indicatrix in the solid angle range of $4 \pi$, and the quantity of cross sections is determined [22], which is necessary to perform the averaging of anisotropy factor. From the other side, the Monte Carlo simulation of light propagation in the system "BT + ER" occurs from the standpoint of the scattering phase function axial symmetry. The differential estimation of spatial distribution by cross section can be ensured similar to the real experiment [21-23]. However, authors of the current research consider that the use of photometric images, which were derived from the method of mirror ellipsoids of revolution during the modal experiment in reflected and transmitted light, is feasible for specifying the tissue anisotropy factor, which was received during the real experiment.

\section{Problem statement}

Considering the mentioned information, the goal of the current investigation is development of the method for determination of tissue scattering anisotropy factor by the analysis of illuminance of different zones of photometric images, received during the photometry by ellipsoidal reflectors.

\section{Photometer with ellipsoidal reflectors}

In the current research the modification of the photometer with ellipsoidal reflectors was used, which was similar to ones, used in the proceedings [18-22, 24]. Fig. 1 represents the photometer scheme, which contains ellipsoidal reflectors for transmitted (ER 1) and reflected (ER 2) light, optical hoods $\mathrm{OH} 1$ and $\mathrm{OH} 2$, adjusting optical systems $\mathrm{L} 1$ and $\mathrm{L} 2$, and cameras CCD 1 and CCD 2.
Ellipsoidal reflector is a mirror ellipsoid of revolution with internal reflecting surface, which was cut by focal planes orthogonally to its major semi-axis; at the same time its minor semi-axes are equal. By means of the reflecting prism $\mathrm{P}$, which was fitted in the laser source tube, the optical radiation is directed into the biological tissue sample, which is located between ER 1 and ER 2 in the corresponding focal planes. Laser source tube is centered relatively to the minor semi-axis of ER 2, and prism $P$ refracts the optical axis on $90^{\circ}$ in the ellipsoid center. Forward and back scattered light leave the borders of biological tissue, which coincides with the first focal planes ER 1 and ER 2 and collected by them. Due to the one-time and multiple reflections from the side surfaces of ellipsoids, the light is transmitted in their second focal plane for further projecting on the photo-receiving surface of CCD cameras by the adjustment optics L 1 and L 2. It is important to note that the first focal plane of ellipsoidal reflector (according to terminology, introduced in proceedings $[19,20,25])$ is the contact surface with the investigated media, and can be called bottom one; at the same time, the second focal plane is called top one, and it is the surface for formation of photometric image. Conic hoods $\mathrm{OH} 1$ and $\mathrm{OH} 2$ have internal black opaque surface, they are used for limitation of undesirable over-reflectance, which can occur due to the non-uniform actuation of side surface of ER and diffraction on the tube of laser source in prism.

Fig. 2, $a, b$ represents the photometric image model of forward and back scattered light on the surface of chicken muscle tissue sample with the thickness $2.14 \mathrm{~mm}$, which was received during the simulation [19] using optical hoods, optical systems, and CCD cameras without ellipsoidal reflectors. Fig. 2, c, $d$ demonstrates the 3D model of forward and back scattered light, which leave the biological tissue sample (the blue color axis coincides with the light distribution direction). The beam length on Fig. 2, $c, d$ is normalized on the initial photon weight, which entered the biological media.

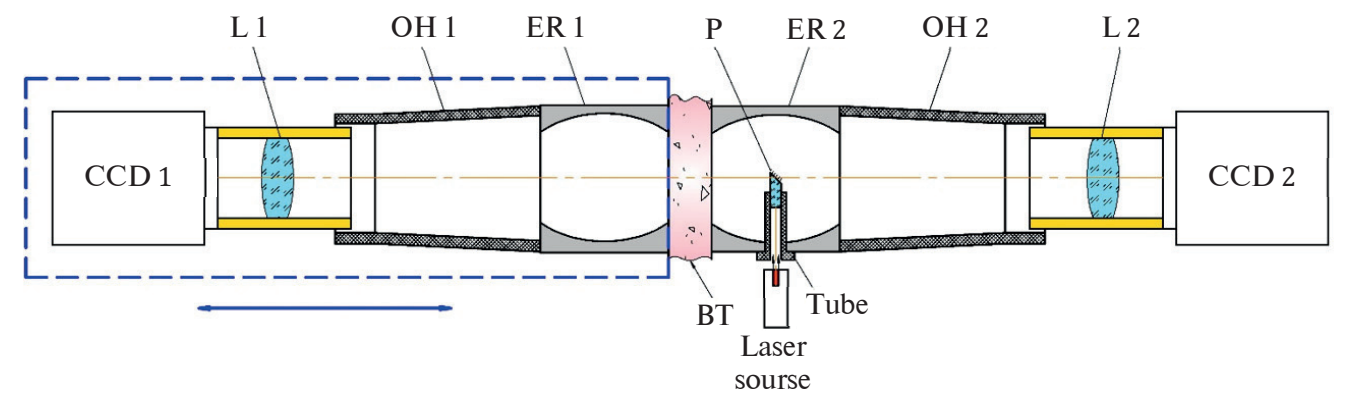

Fig. 1. Photometer with ellipsoidal reflectors 


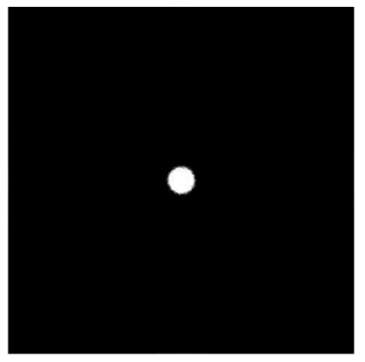

$a$

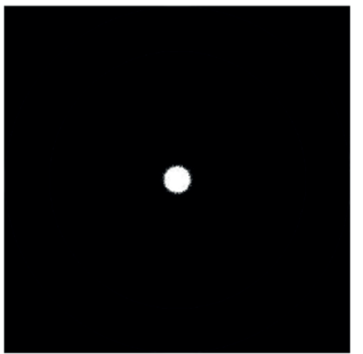

b

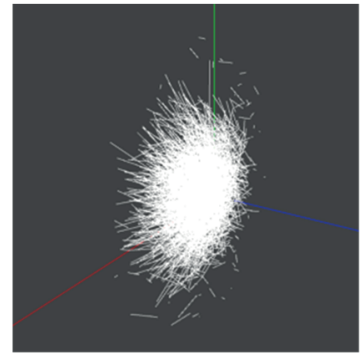

$c$

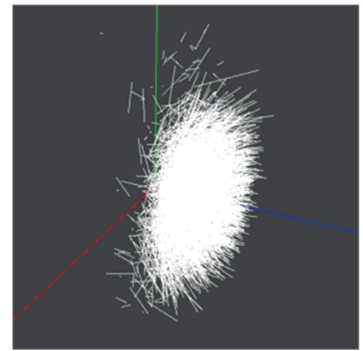

$d$

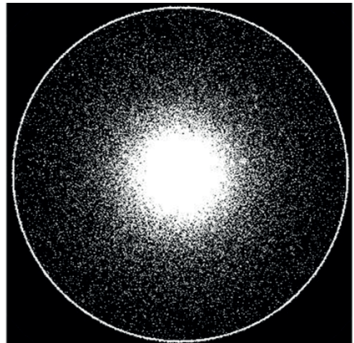

$e$

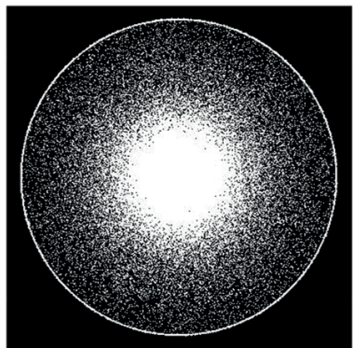

$f$
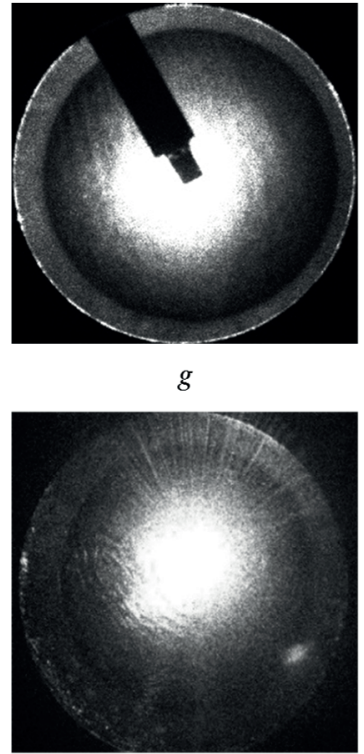

$h$

Fig. 2. Light scattering by the chicken muscle tissue sample with thickness $2.14 \mathrm{~mm}$ : photometric images of top (a) and bottom (b) surfaces of BT sample; 3D visualization of back $(c)$ and forward $(d)$ scattered photons; photometric images of second focal plane of ER as a result of Monte Carlo simulation, and as a result of real experiment in reflected $(e, g)$ and transmitted $(f, h)$ respectively

Fig. 2, $e, f$ represents the photometric images of the second focal plane of ER, received during the simulation of light propagation in the same biological tissue with the use of ellipsoidal reflectors for scattered light collecting. Fig. 2, $g, h$ represents photometric images in scattered and transmitted light in the real experiment.

During analysis of Fig. 2, it is possible to observe advantages of ellipsoidal reflectors using during the scattered light photometry from both standpoints: increased specific weight of registered radiation, and information about intensity of spatial zone distribution. The boundary zone (external ring [25]) of photometric image characterizes the wide-range scattering of BT sample, formed as a result of multiple reflections from underside and upper parts of ellipsoidal reflectors.

\section{Methods and tools}

As the initial data for model experiment, in the current research were used optical properties of chicken and porcine muscle tissues (the Table) with transversal fiber positioning were used. Such data were derived from previous investigations of authors for non-frozen sections of various thicknesses on the

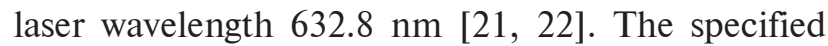
optical properties have good correlation with values, represented in proceedings of other authors [26-28] for muscle tissues of both chicken and porcine.

Table. Optical properties of muscle tissue

\begin{tabular}{|l|c|c|c|c|}
\hline \multicolumn{1}{|c|}{ Tissue } & $\mu_{a}, \mathrm{sm}^{-1}$ & $\mu_{s}, \mathrm{sm}^{-1}$ & $n$ & $g_{H G}$ \\
\hline $\begin{array}{l}\text { Porcine } \\
\text { muscle }\end{array}$ & 1.68 & 45.4 & 1.40 & $0.964-0.982$ \\
\hline $\begin{array}{l}\text { Chicken } \\
\text { muscle }\end{array}$ & 0.9 & 229.9 & 1.37 & $0.946-0.984$ \\
\hline
\end{tabular}

For modeled estimate there were used average values for absorption $\mu_{\mathrm{a}}$ and scattering $\mu_{s}$ coefficients, and in addition the range of HGPF anisotropy factor change, which was received on various cross sections [21] for samples of various thickness [13]. Despite the significant dependency of precision of one-time scattering anisotropy factor determination from scattering indicatrix for biological tissues thickness sample [29], the research investigates the influence of value $\mathrm{g}_{\mathrm{HG}}$ of specific thickness on the light scattering in forward and back directions during the photometry by ellipsoidal reflectors.

The dependency of optical coefficients of diffuse reflectance $\mathrm{Rd}$, absorption $\mathrm{A}$, and total transmittance $T$ from the thickness of investigated sample for different values of tissue anisotropy factor is represented on Fig. 3. 


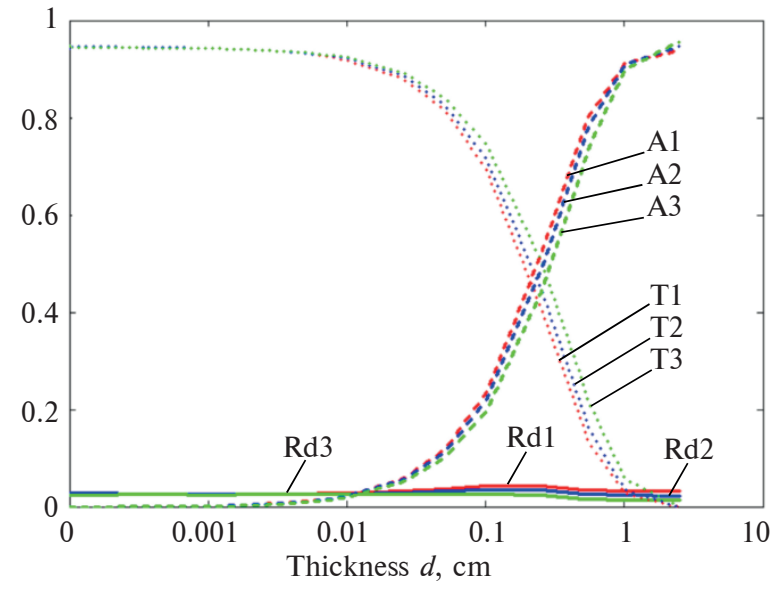

a

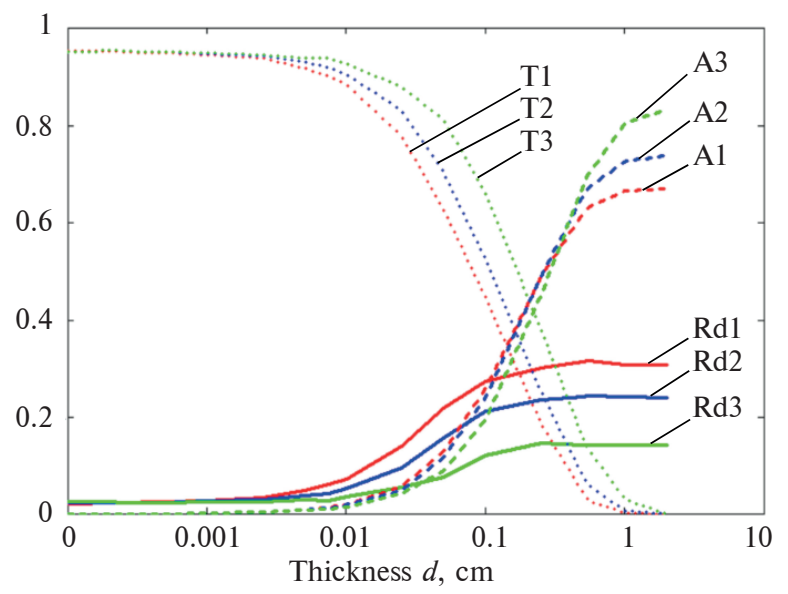

b

Fig. 3. Optical coefficients of diffuse reluctance Rd, total transmittance $\mathrm{T}$ and absorption A from tissue thickness for porcine $(a)$ and chicken $(b)$ muscle tissue
Considering the correlation between theoretical and practical values of illuminance of different zones of photometric images, described in proceedings $[19,25]$, and specificities of the graphs of porcine and chicken muscle tissues optical coefficients (Fig. 3), it is possible to forecast BT sample thicknesses, for which there will be observed the brightest distributions of diffuse transmitted and reflected light during the photometry by ER. In this specific case, for the muscle tissue of chicken such thicknesses are within the range $0.01-5 \mathrm{~mm}$ and for porcine muscle tissue in the range $0.025-7.5 \mathrm{~mm}$. For the modeled similarity, during the further simulation assume to use the thickness $1 \mathrm{~mm}$ for both tissues, and also thicknesses $0.05 \mathrm{~mm}$ and $2.5 \mathrm{~mm}$ for chicken muscles, and $3 \mathrm{~mm}$ and $4 \mathrm{~mm}$ for porcine muscles. The mentioned values define the boundary thicknesses, which were investigated in the real experiment.

\section{Investigation results}

Monte Carlo simulation of light propagation in the system of biomedical photometer with ellipsoidal reflectors [19, 25] foresees the launch of 21.5 million of photons with Gauss cross-section profile [20] of single-mode radiation of He-Ne laser. The variable value during the simulation was the tissue anisotropy factor (see the Table). As a result of modeling, photometric images of second focal plane of ellipsoidal reflectors in reflected and transmitted light for muscle tissues of porcine (Fig. 4) and chicken (Fig. 5) were received.

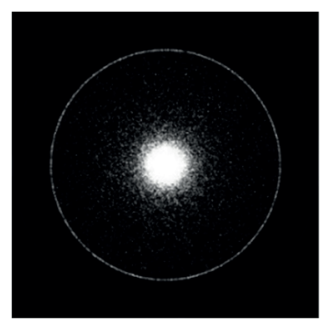

$a$

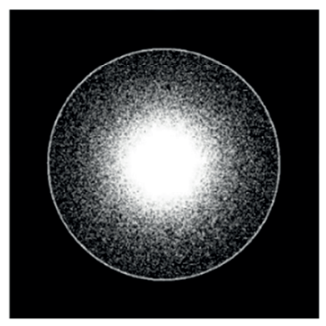

b

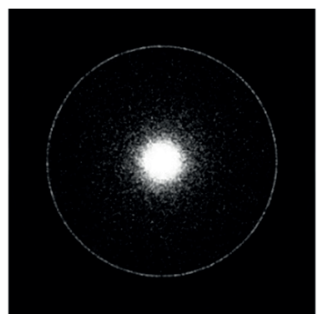

c

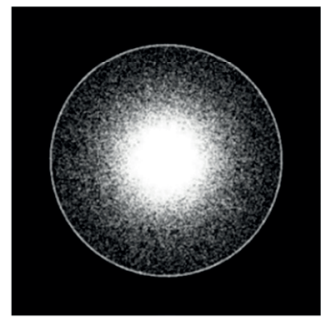

$d$

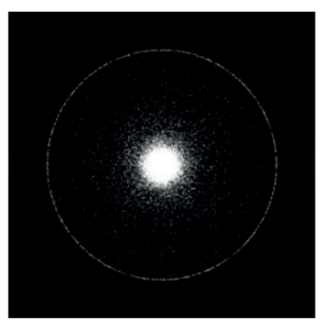

$f$

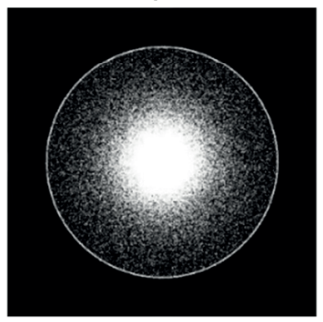

h

Fig. 4. Photometric images of light scattering, obtained at photometry by ellipsoidal reflectors for the sample of porcine muscle tissue $1 \mathrm{~mm}$ thick in the simulation for reflected $(a),(c)$ and $(f)$ as well as transmitted $(b),(d)$ and $(h)$ light respectively for anisotropy factor $g=0.964(a, b), g=0.972(c, d), g=0.982(f, h)$ 
Fig. 4 shows that the illuminance of external and middle rings $[19,25]$ of photometric images in both reflected and transmitted lights changes insignificantly (depending on the change of the porcine muscle tissue anisotropy factor). Other character can be observed for the similar dependency for chicken muscle tissue. It can be clearly observed on Fig. 5 that the illuminance of the middle ring in the scattered light decreases, and in transmitted light increases. For quantitative estimation there were used principles of zone analysis for photometric image processing during the photometry by ellipsoidal reflectors [25], and the results for normalized illuminance relatively to the incident light are represented in $\mathrm{pix} / \mathrm{sm}^{2}$.

Figs. 6, 7 represent the illuminance of different zones of photometric images for porcine and chicken muscle tissue samples with different thickness depending from the scattering anisotropy factor during the modeling and real experiments.

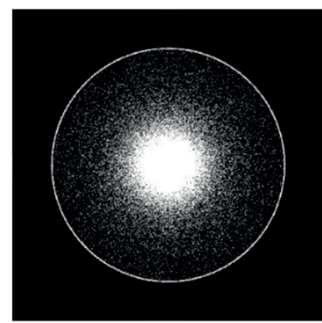

$a$

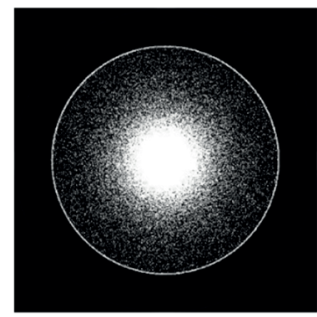

$b$

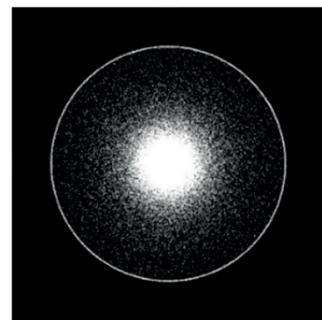

$c$

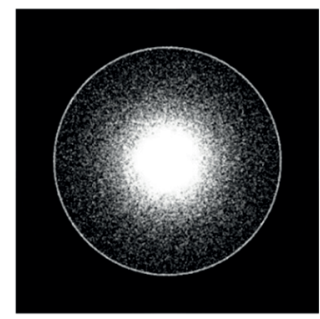

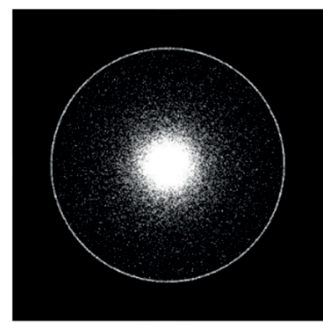

$f$

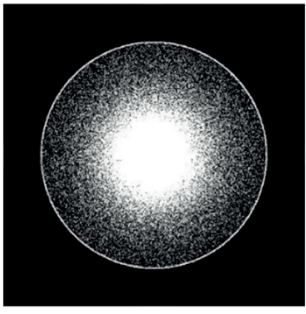

Fig. 5. Photometric images of light scattering, obtained at photometry by ellipsoidal reflectors for the sample of chicken muscle tissue $1 \mathrm{~mm}$ thick in the simulation for reflected $(a),(c)$ and $(f)$ as well as transmitted $(b),(d)$ and $(h)$ light respectively for anisotropy factor $g=0.946(a, b), g=0.962(c, d), g=0.984(f, h)$

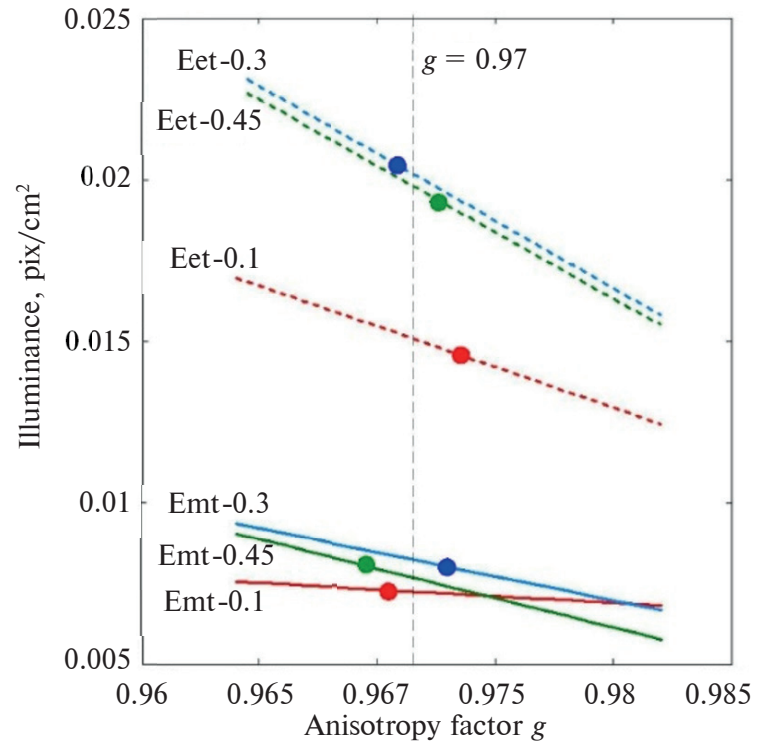

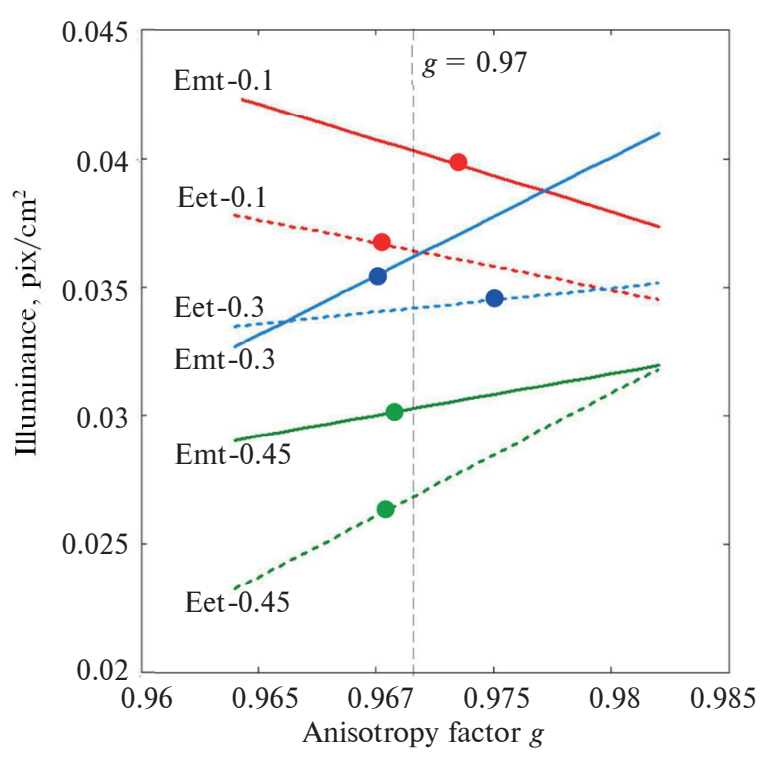

$b$

Fig. 6. Illuminance of external (dashed line) and middle (solid line) rings of photometric images of porcine muscle tissue samples of various thicknesses in reflected $(a)$ and transmitted $(b)$ light 


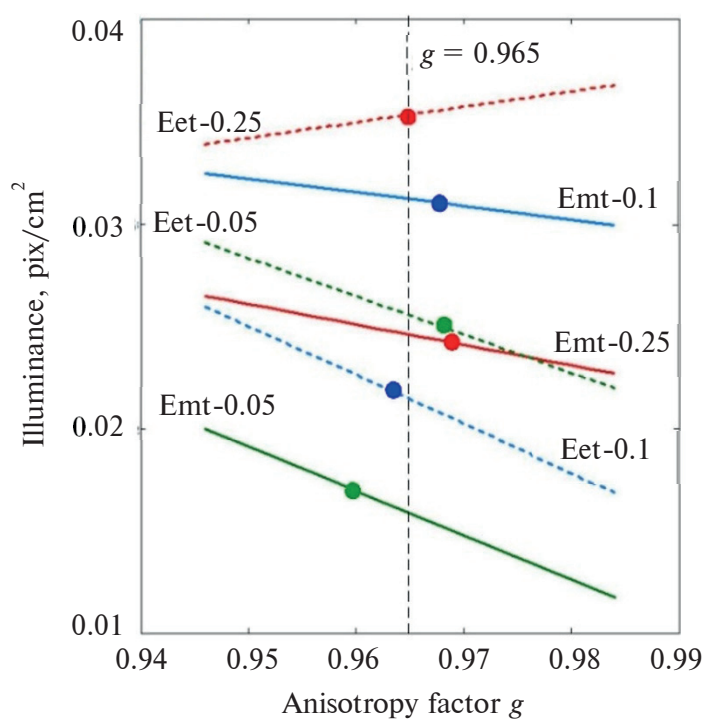

$a$

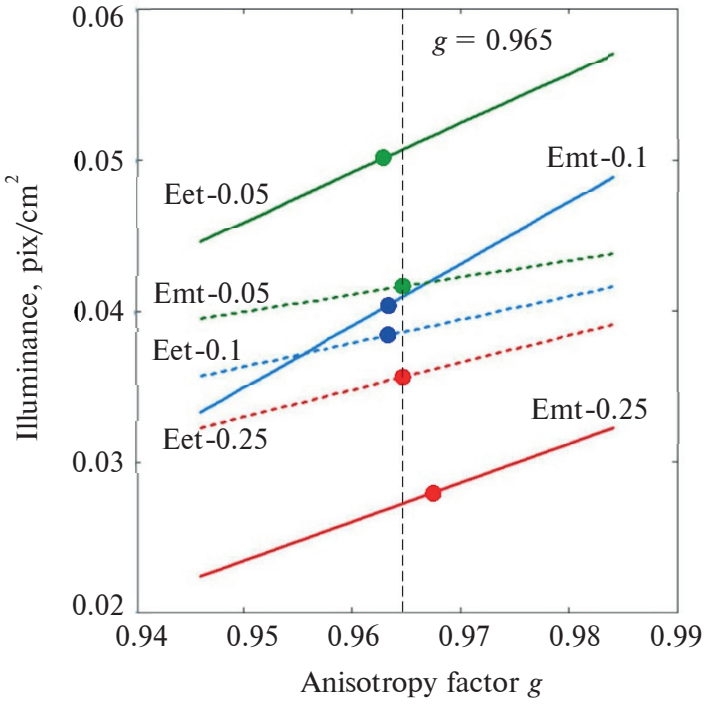

$b$

Fig. 7. Illuminance of external (dashed line) and middle (solid line) rings of photometric images of chicken muscle tissue samples of various thicknesses in reflected $(a)$ and transmitted $(b)$ light

Graphs on Figs. 6, 7 are linear approximation of modeled experiment results during the processing of photometric images, which were received as a single simulation for every value of tissue anisotropy factor. Such approximation by the least squares method has good precision and insignificant divergence comparing to graph, which was constructed as an averaging of external and middle rings illuminance level for 10 simulations series for each value of tissue anisotropy factor. On Figs. 6, 7, there are represented real experiments data for porcine muscle tissue sample of thickness $1 \pm 0.018 \mathrm{~mm}$, $3 \pm 0.021 \mathrm{~mm}$, and $4 \pm 0.023 \mathrm{~mm}$; and additionally for chicken samples of thickness $0.05 \pm 0.008 \mathrm{~mm}$, $1 \pm 0.02 \mathrm{~mm}$, and $2.5 \pm 0.02 \mathrm{~mm} \mathrm{[21]}$.

Comparing the dependency of illuminance of chicken muscle tissue sample photometric images (Fig. 6, $a$ ) and porcine (Fig. 7, $a$ ) of thickness $1 \mathrm{~mm}$ from values of anisotropy factor, it can be noticed the tendency for rapid decrease in external ring illuminance in reflected light, and moderate reduction of middle ring illuminance. At the same time, in the back scattered light the absolute illuminance values for muscle tissues of different animals and for various zones of photometric images drop sharply. Thus, the external ring illuminance for porcine muscle tissue exceeds more than 1.5 times the one of middle ring. At the same time, in the significant range of anisotropy factor change the external ring illuminance for chicken muscle tissue is more than $75 \%$ lower than such of middle ring. Moreover, the middle ring illuminance for chicken muscle tissue exceeds the similar parameter for porcine tissues more than three times; and the illuminance of external ring is almost similar for both investigated tissues. The relative illuminance for different zones of photometric images (created considering possible beam movement trajectories in ER) can express the part of photons, interacted with different parts of ellipsoidal reflector. The ray-tracing mechanism, which was proposed by authors in [19], demonstrate that photons (which set the middle ring illuminance of photometric image) have more remote coordinates of exit from BT comparing to incident area, and higher deflection from the initial direction. Such photons will interact with underside of ellipsoidal reflector with higher probability. The moderate reduction of external ring illuminance for porcine and chicken muscle tissues samples depending on the anisotropy factor reveals the reduction of quantity of back scattered beams, significantly deflected from the incident axis. This notion is true for range of zenith angles inside the aperture range, formed by the second focal plane of ER with diameter equal to doubled focal parameter of ellipsoid of revolution. In such case, the probability of rays reaching the upper part of ER is higher. Considering that the values of optical properties (like absorption coefficient, refractive index, and anisotropy factor (see the Table)) are commensurate for both tissues, and additionally consider the practical identity of external rings illuminance, the fact that scattering 
coefficient value is determinant in the formation of middle ring illuminance is obvious. Moreover, the larger scattering coefficient leads to the increase of the middle ring illuminance in photometric image in the back scattered light.

Let's consider the illuminance of different zones of photometric images for samples of muscle tissues of chicken (Fig. 6, b) and porcine (Fig. 7, b) $1 \mathrm{~mm}$ thick in the transmitted light. The main difference between these two graphs is tangent of inclination of lines: for porcine muscle tissue it is positive, while for chicken one - is negative. Let's consider the tendency of illuminance change for different zones of photometric images for both muscle tissues depending on the various thicknesses of samples (Figs. 6, 7). It is obvious that positive or negative deflection of lines directly correlates with the character of change of optical coefficients of transmission, absorption, and diffuse reflectance (Fig. 3) for the thickness of investigated BE sample. Authors consider that the diffusive reflectance coefficient (the part of rays, scattered in the opposite direction to the incident light) has the determinative influence.

Thus, the methodology for determination of tissue scattering anisotropy factor by the ellipsoidal reflectors method is following. Prior to receiving of photometric images by the photometer with ER (which operates in both reflectance and transmittance directions), it is necessary to determine the thickness of the investigated sample of BT in the format $d \pm \Delta d$. After that, photometry with ellipsoidal reflectors is performed and the illuminance of external and middle rings of photometric images is determine [19, 25]. By inverse Monte Carlo method [30] the optical properties of investigated tissue are calculated, which refers to initial data for Monte Carlo simulation of light propagation in the system "BT + ER" (to initial data there also refer thickness and reflectance coefficients) [19]. The simulation is performed for three values of investigated BT thickness $(d ; d+\Delta d ; d-\Delta d)$ in the significant range of anisotropy factor change for creation of photometric images in the receiving plane of CCD camera. Based on the zone analysis [25] and further averaging of illuminance for the defined thicknesses of investigated BT, the dependencies of external and middle ring of photometric images illuminance in the significant range of tissue anisotropy factor change for forward and back scattered light are created. Photometric image illuminance values, received in the experiment, are plotted on graphs (which were received during Monte Carlo simulation), and determine average values of scattering anisotropy factor on the series of measurements. The corresponding quantity of graphs with plotted results of real experiment during the investigation of samples of the same BT with various thickness are constructed. The scattering anisotropy factor value is averaged by results of all investigated sample thicknesses.

The practical realization of such method (as it can be observed on Figs. 6, 7) has well result reproduction during the investigation of animal muscle tissues. However, it requires additional approbation during the investigation of other BT. In addition, the dependency of anisotropy factor from the sample thickness can't be linearly averaged in all cases. The mentioned aspects will be additionally investigated in future research of authors.

\section{Conclusions}

The mirror ellipsoid of revolution method during the experiment with biological tissues samples in reflected and transmitted light isn't limited only by the functionality of preliminary estimation of section quantity for further spatial analysis and investigation of scattering indicatrix. The photometry by ellipsoidal reflectors can be used as the independent method for determination of tissue anisotropy factor by modeled and numerical experiments by the method represented in the research.

The development of an analytical model that relates the distribution of photometric image illuminance with biological tissue thickness under study and the scattering anisotropy factor is a direction for further research by the authors.

\section{References}

[1] V.V. Tuchin, Optical Biomedical Diagnostics, part 1. Moscow: Russia: Physmathlit, 2007.

[2] O. Nadiarnykh et al., "Alterations of the extracellular matrix in ovarian cancer studied by Second Harmonic Generation imaging microscopy", BMC Cancer, vol. 10, p. 94, 2010. doi: 10.1186/1471-2407-10-94

[3] R.B. La Comb et al., "Quantitative second harmonic generation imaging of the diseased state osteogenesi imperfecta: Experiment and simulation", Biophys. J., vol. 94, no. 11, pp. 4504-4514, 2008. doi: 10.1529/biophysj.107.114405

[4] H. Key et al., "Optical attenuation characteristics of breast tissues at visible and near-infrared wavelengths", Phys Med Biol., vol. 36, no. 5, pp. 579-590, 1991. doi: 10.1088/0031-9155/36/5/002 
[5] A.N. Yaroslavsky et al., "Optical properties of selected native and coagulated human brain tissues in vitro in the visible and near infrared spectral range", Phys. Med. Biol., vol. 47, no. 12, pp. 2059-2073, 2002. doi: 10.1088/0031-9155/47/12/305

[6] P. D. Verhaegenetal., "A reliable, non-invasive measurement tool for anisotropy in normal skin and scar tissue", Skin Res. Technol., vol. 16, no. 3, pp. 325-331, 2010. doi: 10.1111/j.1600-0846.2010.00436.x

[7] S. Chandrasekhar, Radiative Transfer. Dover Publications, 1960.

[8] A. Ishimaru, Wave Propagation and Scattering in Random Media. New York: Academic, 1978,604 p.

[9] W.J. Wiscombe, "Improved Mie scattering algorithms", Appl. Opt., vol. 19, no. 9, pp. 1505-1509, 1980. doi: 10.1364/ao.19.001505

[10] L.O. Reynolds and N.J. McCormick, "Approximate two-parameter phase function for light scattering", J. Opt. Soc. Am., vol. 70, no. 10, pp. 1206-1212, 1980. doi: 10.1364/josa.70.001206

[11] J.H. Joseph et al., "The delta-Eddington approximation for radiative flux transfer", J. Atmos. Sci., vol. 33, no. 12, pp. 2452-2459, 1976. doi: 10.1175/1520-0469(1976)033<2452:tdeafr $>2.0$. co; 2

[12] L.C. Chickenyey and J.L. Greenstein, "Diffuse radiation in the galaxy”, Astrophys. J., vol. 93, pp. 70-83, 1941. doi: $10.1086 / 144246$

[13] S.L. Jacques et al., "Angular dependence of chickene laser light scattering by human dermis", Lasers in the Life Sciences, vol. 1, no. 4, pp. 309-333, 1987.

[14] G. Hall et al., "Goniometric measurements of thick tissue using Monte Carlo simulations to obtain the single scattering anisotropy coefficient”, Biomed. Optics Express, vol. 3, no. 11, 2707-2719, 2012. doi: 10.1364/boe.3.002707

[15] P. Saccomandi et al., "Goniometric measurement for the estimation of anisotropy coefficient of human and animal pancreas", in Proc. 37th Annual International Conference of the IEEE Engineering in Medicine and Biology Society, 2015, pp. $1283-1286$. doi: 10.1109 /embc. 2015.7318602

[16] D. Fukutomi et al., "Determination of the scattering coefficient of biological tissue considering the wavelength and absorption dependence of the anisotropy factor", Optical Rev., vol. 23, no. 2, pp. 291-298, 2015. doi: 10.1007/s10043-015-0161-y

[17] P. Saccomandi et al., "Estimation of anisotropy coefficient of swine pancreas, liver and muscle at 1064 nm base dongoniometric technique", J. Biophoton., vol. 8, no. 5, pp. 422-428, 2015. doi: 10.1002/jbio.201400057

[18] M.A. Bezuglyi and N.V. Bezuglaya, "Ellipsoidal reflectors in biomedical diagnostic", in Proc. SPIE, vol. 9032, 2013. doi: $10.1117 / 12.2044606$

[19] M.A. Bezuglyi et al., "Ray tracing in ellipsoidal reflectors for optical biometry of media", Appl Opt., vol. 56, no. 30, pp. 8520-8526, 2017. doi: 10.1364/AO.56.008520

[20] M.A. Bezuglyi et al., "Influence of laser beam profile on light scattering by human skin during photometry by ellipsoidal reflectors", Devices and Methods of Measurements, vol. 9, no. 1, pp. 56-65, 2018. doi: 10.21122/2220-9506-2018-9-1-56-65

[21] N.V. Bezuglaya et al., "The influence of the axial anisotropy of the scattering by biological media on the accuracy of determination the optical coefficients by Monte Carlo method", Naukovi Visti NTUU KPI, no. 1, pp. 85-91, 2015.

[22] N.V. Bezuglaya et al., "Features of anisotropy of light scattering on fibrous biological tissues", Bulletin of NTUU "KPI". Series Instrument Making, vol. 50, no. 1, pp. 169-175, 2015.

[23] N.V. Bezuglaya and M.A. Bezuglyi, "Spatial photometry of scattered radiation by biological objects", in Proc. SPIE, 2013, vol. 9032, pp. Q1-Q5. doi: https://doi.org/10.1117/12.2044609

[24] M.A. Bezuglyi, "The non-invasive optical glucometer prototype with ellipsoidal reflectors", in Proc. 59th International Scientific Conference on Power and Electrical Engineering of Riga Technical University, 2018, pp. 1-4. doi: 10.1109/RTUCON.2018.8659864

[25] M.A. Bezuglyi et al., "Image processing at ellipsoidal photometry", Devices and Methods of Measurements, vol. 7, no. 1, pp. 67-76, 2016. doi: 10.21122/2220-9506-2016-7-1-67-76

[26] S. Grabtchak et al., "Optical absorption and scattering properties of bulk porcine muscle phantoms from interstitial radiance measurements in 650-900 nm range", Physics in Medicine and Biology, vol. 59, no. 10, pp. 2431-2444, 2014. doi: 10.1088/0031-9155/59/10/2431

[27] A.N. Bashkatov et al., "Optical properties of skin, subcutaneous, and muscle tissues: a review", J. Innov. Optical Health Sci., vol. 4, no. 1, pp. 9-38, 2011. doi: 10.1142/s1793545811001319

[28] S.L. Jacques, "Optical properties of biological tissues: a review", Physics in Medicine and Biology, vol. 58, no. 11, pp. 5007-5008, 2013. doi:10.1088/0031-9155/58/11/r37

[29] S.A. Prahl, "Light transport in tissue", Ph.D. dissertation, University of Texas at Austin, 1988. 
М.О. Безуглий, Н.В. Безугла, Д.В. Горбань

\section{ВИЗНАЧЕННЯ ФАКТОРА АНІЗОТРОПІЇ ТКАНИНИ МЕТОДОМ ФОТОМЕТРІЇ ЕЛІПСОЇДАЛЬНИМИ РЕФЛЕКТОРАМИ} тканин.

Проблематика. Особливості визначення фактора анізотропії розсіяння при дослідженні товщинних зразків біологічних

Мета дослідження. Розробка й апробація нової методики визначення фрактора анізотропії розсіяння тканини через аналіз освітленості різних зон фотометричних зображень, отриманих при фотометрії еліпсоїдальними рефлекторами.

Методика реалізації. Для імплементації ідей та припущень у роботі використовуються засади фотометрії еліпсоїдальними рефлекторами для реального і модельного експериментів при використанні прямого та інверсного методів Монте-Карло поширення оптичного випромінювання в біологічній тканині. Також застосовано принципи зонного аналізу освітленості фротометричних зображень, отриманих у ході фотометрії еліпсоїдальними рефлекторами

Результати дослідження. На підставі результатів реального експерименту представлено вхідний набір даних для симуляції Монте-Карло поширення світла в біомедичному фотометрі з еліпсоїдальними рефрлекторами. На підставі моделювання обґрунтовано вибір граничних товщин зразків м'язової тканини курки та свині для подальшого зіставлення з результатами реального експерименту. Для вибраних товщин у значущому діапазоні змін величини фактора анізотропії, визначеному в перетинах просторового розсіяння, отримано залежності освітленості різних зон фотометричних зображень. Проведено порівняльне оцінювання характеру залежності освітленості зон фотометричних зображень для зразків різних м'язових тканин однакової товщини, а також різної товщини для окремих тканин. На підставі розробленої методики показано особливості відтворюваності результатів реального експерименту при визначенні фрактора анізотропії розсіяння за величинами освітленості фотометричних зображень, отриманих при симуляції.

Висновки. Метод дзеркальних еліпсоїдів обертання при проведенні експерименту для зразків біологічних тканин у відбитому та пропущеному світлі не обмежується функціоналом попередньої оцінки кількості перетинів для подальшого просторового аналізу та дослідження індикатриси розсіяння. Фотометрія еліпсоїдальними рефлекторами може бути використана як самостійний метод визначення величини фактора анізотропії розсіяння за результатами модельного і числового експериментів та за розробленою методикою.

Ключові слова: еліпсоїдальний рефлектор; фотометрія; фрактор анізотропії розсіяння; симуляція Монте-Карло.

\section{М.А. Безуглый, Н.В. Безуглая, Д.В. Горбань}

\section{ОПРЕДЕЛЕНИЕ ФАКТОРА АНИЗОТРОПИИ ТКАНИ МЕТОДОМ ФОТОМЕТРИИ ЭЛЛИПСОИДАЛЬНЫМИ РЕФЛЕКТОРАМИ}

Проблематика. Особенности определения фактора анизотропии рассеяния при исследовании толщинных образцов биологических тканей.

Цель исследования. Разработка и апробация новой методики определения фрактора анизотропии рассеяния ткани путем анализа освещенности различных зон фотометрических изображений, полученных при фотометрии эллипсоидальними рефлекторами.

Методика реализации. Для имплементации идей и предположений в работе используются принципы фотометрии эллипсоидальными рефлекторами для реального и модельного экспериментов при использовании прямого и инверсного методов Монте-Карло распространения оптического излучения в биологической ткани. Также применены принципы зонного анализа освещенности фотометрических изображений, полученных в ходе фотометрии эллипсоидальными рефректорами.

Результаты исследования. На основании результатов реального эксперимента представлен входной набор данных для симуляции Монте-Карло распространения света в биомедицинском фотометре с эллипсоидальными рефлекторами. На основании моделирования обоснован выбор граничных толщин образцов мышечной ткани курицы и свиньи для дальнейшего сопоставления с результатами реального эксперимента. Для избранных толщин в значимом диапазоне изменений величины фактора анизотропии, определенном в сечениях пространственного рассеяния, получены зависимости освещенности различных зон фотометрических изображений. Проведена сравнительная оценка характера зависимости освещенности зон фотометрических изображений для образцов различных мышечных тканей одинаковой толщины, а также различной толщины для отдельных тканей. На основании разработанной методики показаны особенности воспроизводимости результатов реального эксперимента при определении фрактора анизотропии рассеяния по величинам освещенности фотометрических изображений, полученных при симуляции.

Выводы. Метод зеркальных эллипсоидов вращения при проведении эксперимента для образцов биологических тканей в отраженном и пропущенном свете не ограничивается функционалом предварительной оценки количества сечений для дальнейшего пространственного анализа и исследования индикатрисы рассеяния. Фотометрия эллипсоидальными рефлекторами может быть использована как самостоятельный метод определения величины фрактора анизотропии рассеяния по результатам модельного и численного экспериментов и по разработанной методике.

Ключевые слова: эллипсоидальный рефрлектор; фотометрия; фактор анизотропии рассеяния; симуляция Монте-Карло.

Рекомендована Радою

приладобудівного факультету

КПІ ім. Ігоря Сікорського
Надійшла до редакції

29 липня 2019 року

Прийнята до публікації 05 вересня 2019 року 